\title{
Students' acceptance of song lyrics containing national characters
}

\author{
Prana Dwija Iswara ${ }^{* 1,}$ Sandie Gunara ${ }^{2}$, and Julia $^{3}$ \\ ${ }^{1,3}$ Elementary School Teacher Education, Universitas Pendidikan Indonesia Kampus Sumedang, Jl. \\ Mayor Abdurahman 211 Sumedang \\ ${ }^{2}$ Music Education, Faculty of Arts and Design Education, Universitas Pendidikan Indonesia, Jl. Dr. \\ Setiabudi 229 Bandung
}

\begin{abstract}
This paper aims at analyzing the acceptance of elementary school students of song lyrics containing national characters. The study was employed using research and development method, and this paper is the result of the interview related to the learning of nine song lyrics containing national characters. The results showed that all students had no difficulty in learning the vocabulary in the lyrics. However, the students were generally passive when asked about the meaning of the lyrics, hence the ability of students in singing the songs does not represent their understanding of the content of the lyrics. The implication of this research is that students always love songs and can sing songs, but it does not guarantee that students really understand the contents of the song. Keywords: national character, song lyrics, elementary school.
\end{abstract}

\section{Introduction}

This research was conducted to create songs that contain national character for elementary school children. As the phenomenon that occurs in Indonesia today, primary school-age children tend to consume songs for adults, which lyrics are mainly about adult love stories. We cannot directly blame the children, because the parents and Indonesian people in general do not filter song contents that are suitable for children. Meanwhile, the electronic media does not always consider this issue in broadcasting their content because their goal is the commercialization of songs or the entertainment industry. Therefore, they pay less attention to who watch their contents. This song commercialization is inseparable from how the lyrics are made. Lyrics can be used to predict personalities [1]. Hence, one's personality can be used to identify a genre and song classification, and vice versa.

Song writing is basically following the current social situation [1]. From time to time, they have changed relatively according to the social situation and the economic condition of the society. Therefore, the political situation will also affect the song lyrics theme development and will be influenced by the growing social situation in society.

Nowadays, writers of children songs are increasingly disappearing [2]. Moreover, nationwide writers of children song are currently quite difficult to find. Therefore, children's songs that have new nuance and contextual to world of children, and that are

\footnotetext{
* Corresponding author: iswara@upi.edu
} 
popular in the community are hard to find. In fact, to some extent, songs that are part of musical activities have a role in building children's character.

On a study from Lee [3], it was found that, when musical activities are combined with character development, children are better equipped to proactively address problems in their daily lives. Likewise, de Vries [4] suggests the use of music education as a medium to teach value to children. Therefore, we can be sure that the inception of good behavior to children can be done using songs as media.

In Indonesia, in the last few years, character education is emphasized to build 18 characters, consisting of religious, honest, tolerant, disciplined, hard working, creative, independent, democratic, curios, nationalistic, loving his/her country, appreciative for achievements, friendly/communicative, peace loving, avid reader, caring for the environment, have social awareness, and responsible [5]. Thus, to inculcate these characters to the children through songs, it is necessary to write songs that contain or relate to the characters, and to teach them to elementary school children. This is the main purpose of this study, which is to create songs containing national characters for elementary school children. The songs were tested on elementary school children to see their ability to sing the melody of the songs and their understanding of the lyrics. This paper is limited to the limited trial stages, and what is described here is focused on the aspect of the song lyrics, especially on students' acceptance of the song content with a total of nine song lyrics.

\section{Methods}

This paper is the survey part from the research and development method [6]. The participants of the study subjects were nineteen chosen students of Wargaluyu Elementary School. The researchers collected data by survey complemented by observation and question and answer sessions with the students. The analysis of the data that has been obtained through survey, observation and question and answer session was employed by analyzing the attitude and understanding of the song lyrics. The data that has been analyzed were then described, categorized with relevant theories, and concluded.

\section{Results}

The results of this study through observations and discussions of the nine song lyrics taught to 19 students of Wargaluyu Elementary School are described as follows.

Table 1. The Understanding, attitude and acceptability of the song lyrics

\begin{tabular}{|c|c|c|c|c|}
\hline No & Theme & Lyrics & Understanding & $\begin{array}{l}\text { Students } \\
\text { Attitude }\end{array}$ \\
\hline 1. & Religion & $\begin{array}{l}\text { Mengenal semesta } \\
\text { Alam dengan seluruh ciptaNya } \\
\text { Merenung pencipta } \\
\text { Diri kecil di tengah semesta } \\
\text { Ku ingin mengucapkan tasbihku } \\
\text { padaNya } \\
\text { Bertakbir di bawah ke agungan } \\
\text { namaNya } \\
\text { Syukur hamba pada diriNya } \\
\text { Sujud dengan tangis padaNya } \\
\text { Dosa terasa besar } \\
\text { Berat hamba memikul bebanNya } \\
\text { Tanpa ampunanNya } \\
\text { (Knowing the universe } \\
\text { Nature with all His creations } \\
\text { Contemplating the Creator } \\
\text { Small self in the middle of the } \\
\text { universe } \\
\text { I want to say my tasbih to Him }\end{array}$ & $\begin{array}{l}\text { No student } \\
\text { question the } \\
\text { vocabulary in the } \\
\text { lyrics }\end{array}$ & $\begin{array}{l}\text { All students are } \\
\text { passive in the } \\
\text { Q\&A, but all } \\
\text { students accept } \\
\text { the lyrics well }\end{array}$ \\
\hline
\end{tabular}




\begin{tabular}{|c|c|c|c|c|}
\hline & & $\begin{array}{l}\text { Say takbir to His name } \\
\text { Thankful to Him } \\
\text { Head down with tears for Him } \\
\text { The sins feel heavy } \\
\text { This servants can't carry the } \\
\text { burden } \\
\text { Without His forgiveness) }\end{array}$ & & \\
\hline 2. & Honesty & $\begin{array}{l}\text { Sungguh beruntung berkata } \\
\text { jujur } \\
\text { Menjadi benar dan terpercaya } \\
\text { Tempat menitip segala urusan } \\
\text { Dan mencari amanat yang } \\
\text { disimpan } \\
\text { Betapa indah menjaga lidah } \\
\text { Menghindar dari bohong dan } \\
\text { fitnah } \\
\text { Memelihara dalam hati yang } \\
\text { bersih } \\
\text { Dan bertekad menjadi teladan } \\
\text { (How lucky to be honest } \\
\text { Be true and trustworthy } \\
\text { A place of all sorts of affairs } \\
\text { And to search for messages } \\
\text { How wonderful to keep the } \\
\text { tongue } \\
\text { From lying and slander } \\
\text { Keep a clean heart } \\
\text { And determined to be an } \\
\text { example) }\end{array}$ & $\begin{array}{l}\text { No student } \\
\text { question the } \\
\text { vocabulary in the } \\
\text { lyrics }\end{array}$ & $\begin{array}{l}\text { All students are } \\
\text { passive in the } \\
\text { Q\&A, but all } \\
\text { students accept } \\
\text { the lyrics well }\end{array}$ \\
\hline 3. & Tolerance & $\begin{array}{l}\text { Bangun toleransi dalam } \\
\text { beragama } \\
\text { Ayo kita lakukan } \\
\text { Jangan perbedaan menjadi } \\
\text { alasan } \\
\text { Untuk pertengkaran } \\
\text { Paham dan aliran rahmat } \\
\text { perbedaan } \\
\text { Hindari pemaksaan } \\
\text { Lepaskanlah fanatisme } \\
\text { Damai hidup bangsaku } \\
\text { (Build tolerance in religion } \\
\text { Let's do it } \\
\text { Do not make differences into a } \\
\text { reason } \\
\text { For a fight } \\
\text { Ideologies and factions are the } \\
\text { merits of differences } \\
\text { Avoid coercion } \\
\text { Let go of fanaticism } \\
\text { Peace live my nation) } \\
\end{array}$ & $\begin{array}{l}\text { No student } \\
\text { question the } \\
\text { vocabulary in the } \\
\text { lyrics }\end{array}$ & $\begin{array}{l}\text { All students are } \\
\text { passive in the } \\
\text { Q\&A, but all } \\
\text { students accept } \\
\text { the lyrics well }\end{array}$ \\
\hline 4. & Discipline & $\begin{array}{l}\text { Mari disiplin ayo kerjakan } \\
\text { Bersama teman hargai waktu } \\
\text { Patuh aturan dan ketentuan } \\
\text { Tertib jangan ada yang terlewat } \\
\text { Di sisiku ada waktu 'tuk dijaga } \\
\text { Tutup waktu kosong dengan } \\
\text { pekerjaan } \\
\text { Tetap gembira saat beban di } \\
\text { pundak } \\
\text { Berdisiplin selalu } \\
\text { (Let discipline let's do it } \\
\text { Together, friends, appreciate } \\
\text { time } \\
\text { Obey rules and regulations }\end{array}$ & $\begin{array}{l}\text { No student } \\
\text { question the } \\
\text { vocabulary in the } \\
\text { lyrics }\end{array}$ & $\begin{array}{l}\text { All students are } \\
\text { passive in the } \\
\text { Q\&A, but all } \\
\text { students accept } \\
\text { the lyrics well }\end{array}$ \\
\hline
\end{tabular}




\begin{tabular}{|c|c|c|c|c|}
\hline & & $\begin{array}{l}\text { Orderly, do not miss a thing } \\
\text { Beside me, there is time to keep } \\
\text { Fill idle times time with work } \\
\text { Stay happy even when there is } \\
\text { burden on the shoulders } \\
\text { Always be disciplined) }\end{array}$ & & \\
\hline 5. & Hard work & $\begin{array}{l}\text { Kerja keras melakukan } \\
\text { kewajibanku } \\
\text { Itulah tugasku } \\
\text { Belajar dan menaati orang } \\
\text { tuaku } \\
\text { Harus kulakukan } \\
\text { Kerja keras merapikan } \\
\text { pekerjaanku } \\
\text { Demi masa depan } \\
\text { Terus bekerja terus belajar } \\
\text { Jangan sampai lalai } \\
\text { (Work hard to do my duty } \\
\text { That's my job } \\
\text { Learning and obeying my } \\
\text { parents } \\
\text { I have to do it } \\
\text { Hard work to tidy up my work } \\
\text { For the future } \\
\text { Keep working continuously } \\
\text { Do not get negligent) }\end{array}$ & $\begin{array}{l}\text { No student } \\
\text { question the } \\
\text { vocabulary in the } \\
\text { lyrics }\end{array}$ & $\begin{array}{l}\text { All students are } \\
\text { passive in the } \\
\text { Q\&A, but all } \\
\text { students accept } \\
\text { the lyrics well }\end{array}$ \\
\hline 6. & Creativity & $\begin{array}{l}\text { Kerja kreatif } \\
\text { Kerja daya akal pencipta } \\
\text { Semesta dalam alam rumah dan } \\
\text { sekolah } \\
\text { Bangun bangsa raharja } \\
\text { Renungkan bahan jadi karya } \\
\text { (Creative work } \\
\text { Work of mind power } \\
\text { Universe at home and school } \\
\text { Build the prosper nation } \\
\text { Reflect on materials into a } \\
\text { product) }\end{array}$ & $\begin{array}{l}\text { No student } \\
\text { question the } \\
\text { vocabulary in the } \\
\text { lyrics }\end{array}$ & $\begin{array}{l}\text { All students are } \\
\text { passive in the } \\
\text { Q\&A, but all } \\
\text { students accept } \\
\text { the lyrics well }\end{array}$ \\
\hline 7. & Independence & $\begin{array}{l}\text { Dalam buaian kasih sayang } \\
\text { ayah ibu } \\
\text { Kita semakin besar beranjak } \\
\text { remaja } \\
\text { Belajar tanggung jawab mandiri } \\
\text { Tidak lagi pantas menyusahkan } \\
\text { Mencoba mengerjakan tugasnya } \\
\text { Berharap sukses saat nanti } \\
\text { dewasa } \\
\text { (In the cradle of mother's and } \\
\text { father's affection } \\
\text { We are becoming teenagers } \\
\text { Learn self-responsibility } \\
\text { No longer troubling } \\
\text { Trying to do his job } \\
\text { Expecting success in adulthood) }\end{array}$ & $\begin{array}{l}\text { No student } \\
\text { question the } \\
\text { vocabulary in the } \\
\text { lyrics }\end{array}$ & $\begin{array}{l}\text { All students are } \\
\text { passive in the } \\
\text { Q\&A, but all } \\
\text { students accept } \\
\text { the lyrics well }\end{array}$ \\
\hline 8. & Democracy & $\begin{array}{l}\text { Demokrasi di kelasmu } \\
\text { Ayo pilih KM mu yang terbaik } \\
\text { Kita jaga perbedaan } \\
\text { Kalau beda itu biasa } \\
\text { (Democracy in your class } \\
\text { Let's choose your best chairman } \\
\text { We maintain differences } \\
\text { Difference is normal) }\end{array}$ & $\begin{array}{l}\text { No student } \\
\text { question the } \\
\text { vocabulary in the } \\
\text { lyrics }\end{array}$ & $\begin{array}{l}\text { All students are } \\
\text { passive in the } \\
\text { Q\&A, but all } \\
\text { students accept } \\
\text { the lyrics well }\end{array}$ \\
\hline 9. & Curiosity & $\begin{array}{l}\text { Luas alam getarkan akal } \\
\text { Panca indra ingin merasakan }\end{array}$ & No student & All students are \\
\hline
\end{tabular}




\begin{tabular}{|l|l|l|l|}
\hline & $\begin{array}{l}\text { Rasa hati ingin ku belajar } \\
\text { Dengan guru di dalam } \\
\text { bimbingnya } \\
\text { (The vast universe shakes the } \\
\text { mind } \\
\begin{array}{l}\text { The senses want to feel } \\
\text { The heart wants me to learn } \\
\text { With a teacher guiding) }\end{array}\end{array}$ & $\begin{array}{l}\text { question the } \\
\text { vocabulary in the } \\
\text { lyrics }\end{array}$ & $\begin{array}{l}\text { passive in the } \\
\text { Q\&A, but all } \\
\text { students accept } \\
\text { the lyrics well }\end{array}$ \\
\hline
\end{tabular}

\section{Discussions}

The results showed that all students were able to sing both the melody and the words in the lyrics quite well. However, during the discussion of the lyrics, students tended to be passive, so it is basically their real understanding of the lyrics were questionable. This behavior is one of the common phenomena in humans in general, that is although they did not understand the lyrics, they were happy and enjoyed the song [7]. In other words, a person can sing, even sing a song in a foreign language without really understanding its meaning. However, even if one does not understand the lyrics of the song, one may be happy to sing the song. Meanwhile, the songs could have contained lust, sin, evil, mistakes, or meanings that lack good value. People just love the song without understanding the meaning of the lyrics [8].

The passivity of the students in the discussions does not represent the students' lack of understanding. Various questions regarding the song lyrics vocabulary were responded with signs that represent the absence of difficulty. However, the form of their understanding of the contents of the lyrics could not be expressed in words. This can also be caused by the students' lack of ability to express their thoughts (opinions) or feelings. Another possibility includes the unwillingness of the student to share their difficulties in understanding the song lyrics to the teacher.

Students preferred to sing and memorize the lyrics of the song. It is indeed quite positive to develop their ability to memorize the whole song, both melodies and lyrics. Even other research find out that people find it easier to remember songs (melodies) and titles better than the lyrics. However, lyrics can help people to remember songs and titles. In contrast, titles and songs cannot help people remember lyrics.

The melodies of songs evoke emotions better compared to lyrics [9]. Therefore, lyrics are actually neutral or being paid less attention by the students in term of their meaning and message. The students favor songs in a way that they only accept the lyrics based on how they like the melody. The students did not pay attention to the lyrics because they pay more attention to the songs. If the students like the songs, they will like the lyrics. Songs can indeed impact people's behavior [10]. On the other hand, studies of one's understanding related to their experience were conducted [11] and [12].

\section{Conclusions}

Based on the limited trial and the findings, students tended to be passive in discussing the contents of the song, they preferred to sing and memorize the lyrics. Therefore, their ability to sing does not necessarily represent their understanding of the vocabulary of the lyrics or the meaning of the song. However, all students accepted the presence of new song lyrics well and they did not show any rejection or confusion when studying it.

In this study, we would like to extend our gratitude to a number of parties who specifically contributed without underrating others who also gave major or minor contributions. Our first gratitude is sent to the Directorate General of Higher Education who provided funds for this study. The second goes to the Institute for Research and Community Service (LPPM) of Universitas Pendidikan Indonesia that helped facilitating this study. 


\section{References}

1. Pettijohn TF, Sacco Jr DF, Journal of Language and Social Psychology. 28 :297-311 (2009).

2. Hendrayana D, Anak-anak Kita Butuh Lagu (Pikiran Rakyat, 26, 9 Juni 2016).

3. Lee A, International Journal of Music Education 34:340-51 (2016).

4. de Vries P, Journal of the Australian Council of Orff Schulwerk 12:14 (2007).

5. Hasan SH, Pengembangan Pendidikan Budaya dan Karakter Bangsa. Materi disajikan sebagai bahan pelatihan Penguatan Metodologi Pembelajaran berdasarkan Nilai-Nilai budaya untuk Membentuk Daya Saing dan Karakter Bangsa (Badan Penelitian dan Pengembangan Kemendiknas, Jakarta, 2010).

6. Sugiyono. Metode Penelitian Pendidikan (Pendekatan Kuantitatif, Kualitatif, dan $R \& D$ (Alfabeta, Bandung, 2006).

7. Peynircioğlu ZF, Rabinovitz BE, Thompson JL, Psychology of Music 36:47-61 (2008).

8. Madanikia Y, Bartholomew K. Themes of lust and love in popular music lyrics from 1971 to 2011. SAGE Open. 4:2158244014547179 (2014).

9. Ali SO, Peynircioğlu ZF, Psychology of Music 34:511-34 (2006).

10. P. Fischer, T. Greitemeyer, PSPB 32 (9): 1165-1176 (2006).

11. J. P. Maxwell, Violence 16 (7): 640-661 (2001).

12. N. Gueguen, C. Jacob, L. Lamy, Psychol. Music 38 (3): 303-307 (2010). 